\title{
Synthesis and characterization of graphite/magnetite composite as low cost potential adsorbent from graphite waste
}

\author{
Eny Kusrini ${ }^{1, *}$, Felix Oktavianto ${ }^{1}$, Agustina Simanjuntak ${ }^{1}$, Giovanni Pasca ${ }^{1}$, and Anwar Usman ${ }^{2}$ \\ ${ }^{1}$ Department of Chemical Engineering, Faculty of Engineering, Universitas Indonesia, Depok 16424, Indonesia \\ ${ }^{2}$ Department of Chemistry, Faculty of Science, Universiti Brunei Darussalam, Jalan Tungku Link, Gadong BE1410, Negara Brunei \\ Darussalam
}

\begin{abstract}
The comparative properties of pre-treated graphite waste and composite with magnetite nanoparticles were studied. The present work describes the thermal-mechanical method for pre-treated graphite electrode waste and chemical modification on the pre-treated graphite waste with magnetite nanoparticles $\left(\mathrm{Fe}_{3} \mathrm{O}_{4}\right)$. The raw material is graphite electrode waste. The variables of temperature and time that affected the properties of pre-treated graphite waste was also observed. Pre-treated of graphite electrode waste was prepared via thermal process at temperatures of $60,75,90^{\circ} \mathrm{C}$ and various times of 30,60 and 90 minutes, followed by mechanical crushing of the resultant graphite waste to $75 \mu \mathrm{m}$ particle size. The synthetic material (graphite waste $/ \mathrm{Fe}_{3} \mathrm{O}_{4}$ composite) was prepared with hydrochloric acid $(0.1 \mathrm{M})$ for activation of the pre-treated graphite waste, followed by chemical modification with pre-treated graphite waste to $\mathrm{Fe}_{3} \mathrm{O}_{4}$ mass ratio 1: $1(\mathrm{w} / \mathrm{w})$. The experimental results showed that the pre-treated graphite waste are non-porous. Effect of magnetite nanoparticles $\left(\mathrm{Fe}_{3} \mathrm{O}_{4}\right)$ revealed that the surface area of graphite waste $/ \mathrm{Fe}_{3} \mathrm{O}_{4}$ composite increased from $8.44 \mathrm{~m}^{2} / \mathrm{g}$ to $64.58 \mathrm{~m}^{2} / \mathrm{g}$. The EDX composition of Fe increased from 0.08 to $38.68 \mathrm{wt} \%$, indicated that the modification of $\mathrm{Fe}_{3} \mathrm{O}_{4}$ nanoparticles onto graphite waste was carried out successfully. This data is useful for the preliminary treatment process of graphite electrode waste for further applications that require adsorbent preparation and modification.
\end{abstract}

\section{Introduction}

Removal of dyes from industrial pollution such as textile industry, dye industries, papermaking, food processing, plastic and rubber dyeing, cosmetics and construction has become a significant problem in the environment and water sources [1-3]. Studies of adsorbents for removal of dyes have gained greater attention since adsorption is one of the most effective methods for the removal of dyes and heavy metal ions from wastewater [2]. Adsorption is general considered as a physical method and is favoured due to its low operating cost and facile design.

Recently, the graphite electrode waste and their composites were used as sorbents for capturing $\mathrm{CO}_{2}$ have been reported [4,5]. Graphite electrode waste can be obtained from the electrolysis processing waste from the aluminum industry. The composition of graphite electrode waste is carbon [4-7]. The characterization and application of graphite waste after chemical modification have been reported as potential adsorbents for removal of $\mathrm{CO}_{2}[4,5]$, and dyes [6]. After treatment of graphite waste by thermal and mechanical methods, the surface area of graphite electrode wastes was variable: $5.9 \mathrm{~m}^{2} / \mathrm{g}$ [6], $8.49 \mathrm{~m}^{2} / \mathrm{g}$ [4], and $26.35 \mathrm{~m}^{2} / \mathrm{g}$ [7]. By surface modification with chemical treatment using $\mathrm{Fe}_{3} \mathrm{O}_{4}$ nanoparticles, the surface area of pre-treated graphite waste increase up to $35.52 \mathrm{~m}^{2} / \mathrm{g}$ [4]. Modification of the graphite surface is one of the wellknown strategies to increase its surface area to improve the mechanical properties and to enable modification of the functional groups on its surface [8].

This work is part of an ongoing study, where in this study, the preparation of pre-treated graphite waste using thermal- mechanical methods and modified of pre-treated graphite waste with magnetite nanoparticles $\left(\mathrm{Fe}_{3} \mathrm{O}_{4}\right)$ are described. The modified materials were characterized using FTIR, SEM-EDX and BET. After synthesis, both prepared materials are used as adsorbent for removal of methyl violet (MV) from aqueous samples in the batch system [6]. In this study, we discuss the characterization of composite and its use as a sorbent to remove the model dye (methyl violet) from aqueous solution. It is expected that the presence of $\mathrm{Fe}_{3} \mathrm{O}_{4}$ nanoparticles on the surface of the graphite waste is able to change the structure of graphite surface and increase the surface area [4]. $\mathrm{Fe}_{3} \mathrm{O}_{4}$ nanoparticles are suitable for removal of dye because it was easier to recover and separat from water [9] to enable regeneration of the adsorbent [10].

\section{Experimental}

Preparation of PTG. Graphite electrode waste was oven-dried at temperatures 60,75 and $90^{\circ} \mathrm{C}$ for 30,60 and 90 minutes. Graphite waste that was dried then mashed with a grinder and filtered with a particle size of 75 microns. The prepared graphite was immersed and soaked with $0.1 \mathrm{M} \mathrm{HCl}$ for $2 \mathrm{~h}$. 
Preparation of Graphite waste/ $/ \mathrm{Fe}_{3} \mathrm{O}_{4}$ composite. $\mathrm{FeCl}_{2} \cdot 4 \mathrm{H}_{2} \mathrm{O}$ with $5.2 \mathrm{~g}$ and $2 \mathrm{~g}$ of $\mathrm{FeCl}_{3} \cdot 6 \mathrm{H}_{2} \mathrm{O}$ were mixed and stirred in the $10.3 \mathrm{~mL}$ of $1 \mathrm{~N} \mathrm{HCl}$. The mixture was diluted with $15 \mathrm{~mL}$ of demineralized water for 15 minutes. Then, the mixture was poured into $250 \mathrm{~mL}$ of $1.5 \mathrm{M}$ ammonium hydroxide to form a black precipitate and was responsive to an external magnetic field. After that, the mixture was continually stirred for $1 \mathrm{~h}$ at room temperature. The $\mathrm{Fe}_{3} \mathrm{O}_{4}$ magnetite nanoparticles was separated from the solution with a permanent bar magnet. The magnetite nanoparticle black precipitate $\left(\mathrm{Fe}_{3} \mathrm{O}_{4}\right)$ was washed using demineralized water until the $\mathrm{pH}$ remained at 7. After that, $1.2 \mathrm{~g}$ of the prepared graphite waste was added into the $\mathrm{Fe}_{3} \mathrm{O}_{4}$ black precipitate and dilute with 100 $\mathrm{mL}$ of water by stirring for 4 hours. The composite was separated from the solution with a permanent magnet bars. The black precipitate was washed with demineralized water until the $\mathrm{pH}$ at 7 . The mixture was heated in oven at a temperature of $60^{\circ} \mathrm{C}$ for $2 \mathrm{~h}$. Then, it was crushed to obtain the graphite $/ \mathrm{Fe}_{3} \mathrm{O}_{4}$ composite with graphite waste to $\mathrm{Fe}_{3} \mathrm{O}_{4}$ mass ratio $1: 1(\mathrm{w} / \mathrm{w})$.

Characterization. Nitrogen adsorption measurement was conducted at $77 \mathrm{~K}$, using an ASAP 2020 V4.02 unit gas adsorption analyzer, at an equilibration interval of 5 sec. The surface area of the adsorbent was determined using the Brunauer, Emmet, and Teller (BET) equation, and the microspore volume of the adsorbent was measured using the t-plot method. The pore size distribution was calculated according to the Barrett, Joyner, and Halenda (BJH) model. The surface morphology, composition and functional groups of the samples were further evaluated by scanning electron microscopy-Energy with energy dispersive X-ray spectroscopy (EDX) (Hitachi, Japan) and Fourier-transform infrared (FTIR) spectroscopy (Hitachi, Japan), respectively.

\section{Results and Discussion}

\subsection{FTIR Studies}

Pre-treatment of graphite electrode waste was carried out by using a heating process at $60^{\circ} \mathrm{C}, 75^{\circ} \mathrm{C}$, and $90^{\circ} \mathrm{C}$ within a specified time range from 30 to 90 minutes. The purpose of these two variations is to determine the optimum of temperature and duration of heating time for pre-treatment graphite waste. After heating the graphite waste, the destruction of graphite into uniform sized particles powder is about $75 \mu \mathrm{m}$. The size of particles correspond to its porosity, which the smaller of particle sizes had the larger the surface area. These affected the adsorption efficiency of sorbent. As similarly reported by Matrin-Gullon [11], the materials with greater surface area contained more micropores, thus the active site and possibility for adsorption was likely. In this study, the best pre-treated of graphite waste was obtained at temperature of $60^{\circ} \mathrm{C}$ and time of 30 minutes, then it was used for further structurally characterized as discussed below.

FTIR spectra of all the sorbents are quite similar. These spectra did not show sharp spectral features before and after modification with $\mathrm{Fe}_{3} \mathrm{O}_{4}$ nanoparticles and after used as sorbent for removal of methyl violet (see Figure 1A -
C). The absorption band for $\mathrm{C}-\mathrm{H}$ bending of monosubstituted benzene and $\mathrm{CH}_{3}$ stretching were observed at $565-749 \mathrm{~cm}^{-1}$ and $2042-2743 \mathrm{~cm}^{-1}$ for all of the FTIR spectra of the pre-treated graphite waste, graphite $/ \mathrm{Fe}_{3} \mathrm{O}_{4}$ composite and after adsorption with methyl violet. As we can see from Fig $1 \mathrm{~A}$, the weak absorption band at $1045 \mathrm{~cm}^{-1}$ was assigned for the stretching of C-O. After modified with $\mathrm{Fe}_{3} \mathrm{O}_{4}$ nanoparticles, this peak was shifted to higher frequency at $1090 \mathrm{~cm}^{-1}$ indicating the interaction between the oxygen atoms from $\mathrm{Fe}_{3} \mathrm{O}_{4}$ nanoparticles and surface of graphite (Fig 1B). Whereas, the characteristic adsorption band corresponding to the $\mathrm{Fe}$ $\mathrm{O}$ bond vibration $\left(582 \mathrm{~cm}^{-1}\right)$ of $\mathrm{Fe}_{3} \mathrm{O}_{4}$ nanoparticles [10] was not observed. However, the Fe metal was observed by EDX (see Table 1).

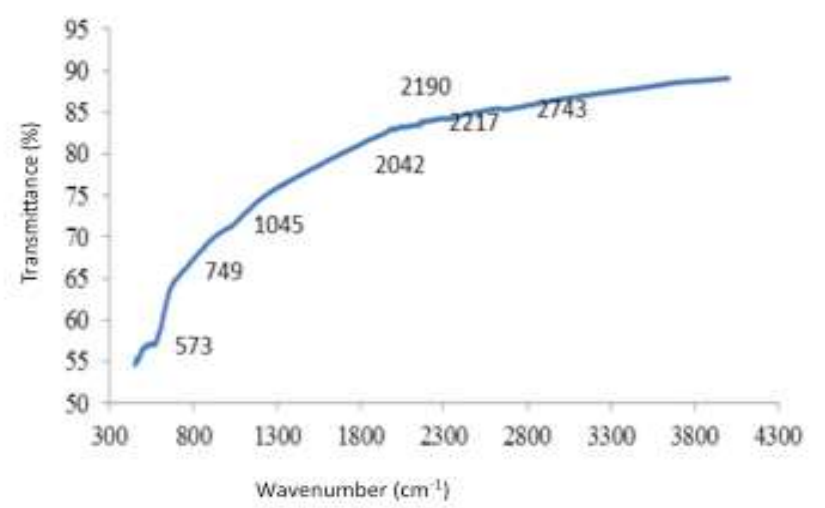

A

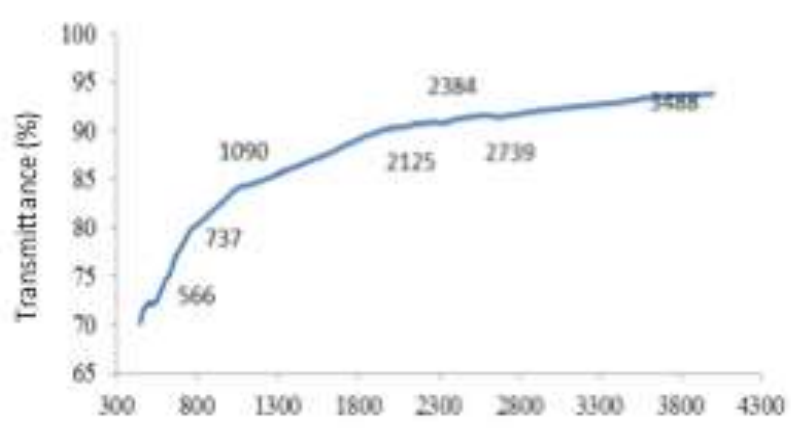

Wavenumber $\left(\mathrm{cm}^{-1}\right)$

B

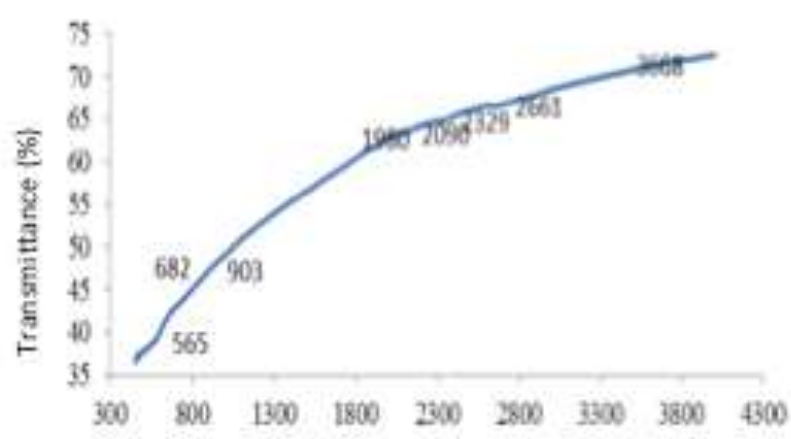

Wavenumber $\left(\mathrm{cm}^{-1}\right)$

$\mathrm{C}$

Fig. 1. FTIR spectra of the pre-treated graphite waste (A), graphite/ $\mathrm{Fe}_{3} \mathrm{O}_{4}$ composite (B) and after adsorption with methyl violet (C) 
The weak peak at $3488 \mathrm{~cm}^{-1}$ was assigned for the hydroxyl $(\mathrm{OH})$ groups and hydrogen bonded was observed in graphite $/ \mathrm{Fe}_{3} \mathrm{O}_{4}$ composite. This result indicates that the hydroxyl groups on the nanoparticle surface was involved in complexation with $\mathrm{Fe}^{3+}$. A similar effect was observed with Cao et al. [12] where it wasreported that the synthesized material was magnetic $\mathrm{Fe}_{3} \mathrm{O}_{4} /$ chitosan nanoparticles. After adsorption with methyl violet, the peak was shifted to $3668 \mathrm{~cm}^{-1}$ (see Fig1C). This indicates that the unassociated hydroxyl group $(\mathrm{OH})$ and $\mathrm{N}-\mathrm{H}$ stretching in composite after adsorption with methyl violet $\left(\mathrm{C}_{24} \mathrm{H}_{28} \mathrm{~N}_{3} \mathrm{Cl}\right)$. It is assumed that hydrogen-bonding was not involved in the composite upon adsorption of MV.

\subsection{Morphology, and Composition Studies}

The SEM images of pre-treated graphite waste and the graphite waste $/ \mathrm{Fe}_{3} \mathrm{O}_{4}$ composite before and after adsorption with a selected model dye (methyl violet) are shown in Figure 2(A-C). Pre-treated graphite waste has small pores that are spaced apart (see Fig 2A). The heating process serves to remove the impurities on the surface of graphite, but it is not sufficient to enlarge the pores of graphite waste. Graphite/ $\mathrm{Fe}_{3} \mathrm{O}_{4}$ composite has more pores to be formed, and larger diameter pores due to the presence of $\mathrm{Fe}_{3} \mathrm{O}_{4}$ nanoparticles. After it is used for adsorption with the model dye (methyl violet), the pore diameter of graphite $/ \mathrm{Fe}_{3} \mathrm{O}_{4}$ composite was reduced. This affect is related to pore filling of the composite with the model dye.

The EDX composition of pre-treated graphite waste, fresh composite graphite waste $/ \mathrm{Fe}_{3} \mathrm{O}_{4}$ and after adsorption was summarized in Table 1. The pre-treated graphite waste has carbon $(\mathrm{C})$ is about $62.65 \mathrm{wt} \%$. After modified with $\mathrm{Fe}_{3} \mathrm{O}_{4}$ nanoparticles, the fresh of graphite waste $/ \mathrm{Fe}_{3} \mathrm{O}_{4}$ composite has composition of carbon is only about 47.51 wt $\%$. It was reduced about $24.1 \%$ compare with the pretreated graphite waste. The carbon content in graphite waste $/ \mathrm{Fe}_{3} \mathrm{O}_{4}$ composite decreased because the addition of $\mathrm{Fe}_{3} \mathrm{O}_{4}$ nanoparticles onto pre-treated graphite waste. While, the composition of iron ( $\mathrm{Fe}$ ) increased from 0.08 to $38.68 \mathrm{wt} \%$, indicated that the modification of $\mathrm{Fe}_{3} \mathrm{O}_{4}$ nanoparticles onto graphite has been successfully impregnated.

The change in morphology and composition of the graphite waste/ $\mathrm{Fe}_{3} \mathrm{O}_{4}$ composite after its use as an adsorbent to remove of methyl violet (MV) in the aqueous solution was noted. After adsorption with the model dye (MV), the composition of carbon is quite similar as compared with the fresh (unused) composite (47.95 wt\%). On the other hand, the composition of iron $(\mathrm{Fe})$ is reduced to $27.06 \mathrm{wt} \%$ because the $\mathrm{Fe}$ ions are bonded with the oxygen atoms of the model dye. Some of metal impurities such as $\mathrm{Si}, \mathrm{Al}, \mathrm{Na}$ and $\mathrm{Ca}$ were also observed in all of the sorbents. Surface area of the prepared materials is shown in Table 2.

A good distribution of the $\mathrm{Fe}_{3} \mathrm{O}_{4}$ nanoparticles is observed on the surface of graphite/ $\mathrm{Fe}_{3} \mathrm{O}_{4}$ composite.

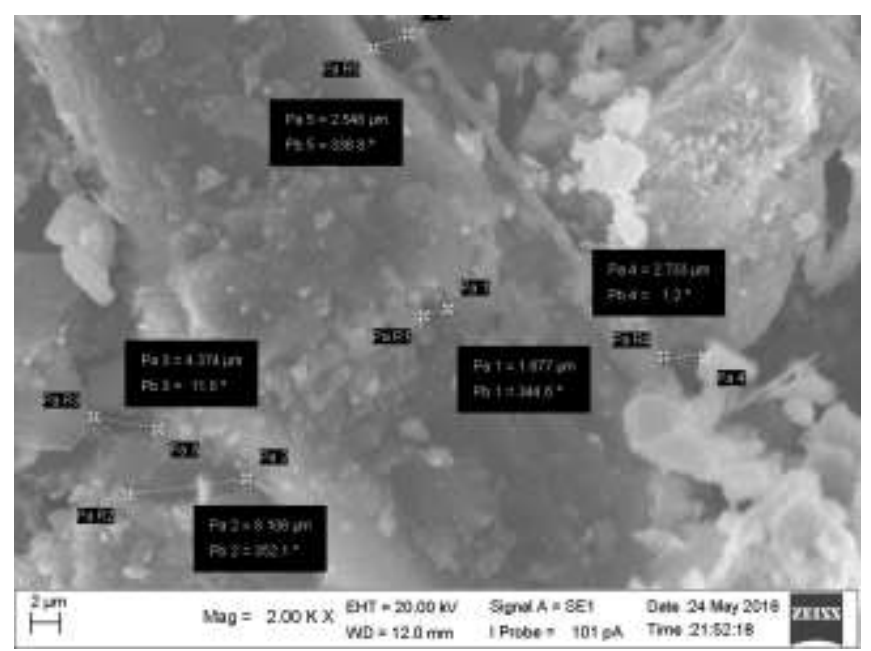

A

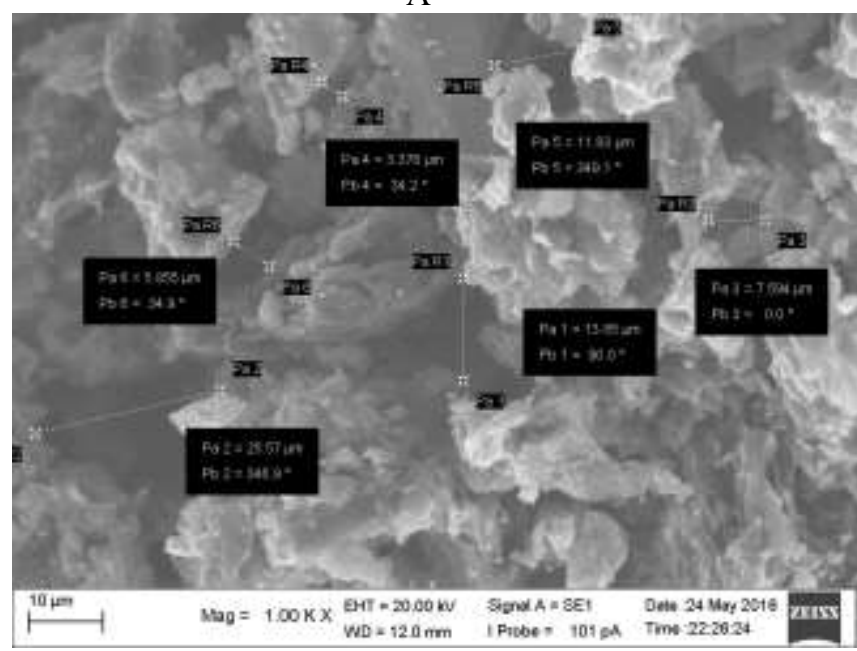

B

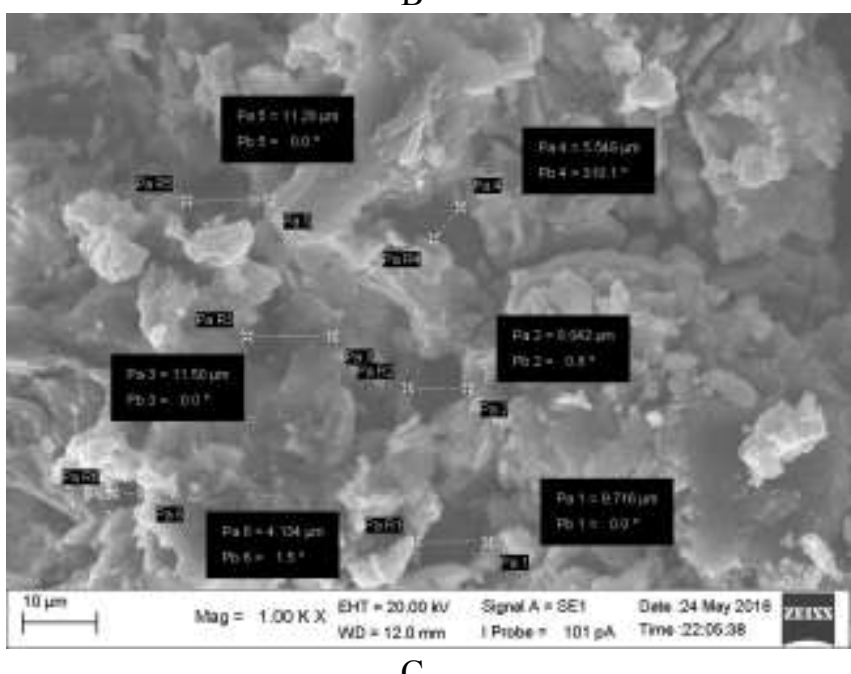

Fig. 2. SEM images of pre-treated graphite waste at $60^{\circ} \mathrm{C}(\mathrm{A})$, the fresh composite of graphite/ $\mathrm{Fe}_{3} \mathrm{O}_{4}(\mathrm{~B})$ and composite after adsorption with MV (C) 
Table 1. EDX composition of pre-treated graphite waste, fresh composite and after adsorption

\begin{tabular}{|c|c|c|c|}
\hline \multirow{2}{*}{ Elements } & \multicolumn{3}{|c|}{ Composition (wt\%) } \\
\cline { 2 - 4 } & PTG & $\begin{array}{c}\text { Fresh of } \\
\text { Graphite/Fe } \mathrm{O}_{4}\end{array}$ & $\begin{array}{c}\text { After } \\
\text { adsorption }\end{array}$ \\
\hline $\mathrm{C}$ & 62.65 & 47.51 & 47.95 \\
\hline $\mathrm{Fe}$ & 0.08 & 37.68 & 27.06 \\
\hline $\mathrm{O}$ & 3.90 & 13.11 & 19.96 \\
\hline $\mathrm{F}$ & 24.07 & - & 3.07 \\
\hline $\mathrm{Na}$ & 7.35 & 0.67 & 0.93 \\
\hline $\mathrm{Al}$ & 1.52 & 0.46 & 0.59 \\
\hline $\mathrm{Si}$ & 0.02 & 0.12 & 0.05 \\
\hline $\mathrm{Ca}$ & 0.40 & 0.45 & 0.38 \\
\hline
\end{tabular}

\subsection{Surface area}

Pre-treated graphite waste is a non-porous material with surface area of $8.44 \mathrm{~m}^{2} / \mathrm{g}$. After modification with $\mathrm{Fe}_{3} \mathrm{O}_{4}$ nanoparticles, the surface area of graphite waste $/ \mathrm{Fe}_{3} \mathrm{O}_{4}$ composite was significantly increased up to $64.58 \mathrm{~m}^{2} / \mathrm{g}$ (Table 2). Pre-treated graphite waste has average pore size of $14.4 \mathrm{~nm}$, whereas the composite has smaller pore size of $10.6 \mathrm{~nm}$.

Table 2. BET surface area of adsorbents

\begin{tabular}{|c|c|c|}
\hline & PTG & Graphite/ $\mathrm{Fe}_{3} \mathrm{O}_{4}$ \\
\hline BET surface Area $\left(\mathrm{m}^{2} / \mathrm{g}\right)$ & 8.44 & 64.58 \\
\hline $\begin{array}{c}\text { Langmuir surface area } \\
\left(\mathrm{m}^{2} / \mathrm{g}\right)\end{array}$ & 53.21 & 506.13 \\
\hline t-plot micropore area & - & 0.118 \\
\hline $\begin{array}{c}\text { t-plot external surface } \\
\left(\mathrm{m}^{2} / \mathrm{g}\right)\end{array}$ & 8.49 & 64.46 \\
\hline $\begin{array}{c}\text { BJH adsorption cumulative } \\
\text { volume of pores }\left(\mathrm{cm}^{3} / \mathrm{g}\right)\end{array}$ & 0.03 & 0.16 \\
\hline $\begin{array}{c}\text { Adsorption pore size width } \\
(\mathrm{nm})\end{array}$ & 14.47 & 10.68 \\
\hline $\begin{array}{c}\text { BJH adsorption average } \\
\text { pore diamater }(\mathrm{nm})\end{array}$ & 15.04 & 10.99 \\
\hline $\begin{array}{c}\text { Nanoparticle size }(\mathrm{nm}) \\
\text { Pore Size }(\mathrm{nm})\end{array}$ & 710.7 \\
\hline
\end{tabular}

\section{Conclusion}

The data reported here is useful for the preliminary characterization and modification of graphite electrode waste. The pre-treated graphite waste was modified using only thermal-mechanical process and showed the potential utility as an effective low-cost adsorbent technology as compared to chemical treatment using $\mathrm{Fe}_{3} \mathrm{O}_{4}$ nanoparticles.
The authors greatly acknowledge the Universitas Indonesia as financial support through Hibah PITTA No. 2431/UN2.R3.1/HKP.05.00/2018.

\section{References}

1. C. Li, Y. Dong, J. Yang, Y. Li, and C. Huang, Modified nano-graphite $/ \mathrm{Fe}_{3} \mathrm{O}_{4}$ composite as efficient adsorbent for the removal of methyl violet from aqueous solution, Journal of Molecular Liquids, Vol. 196, pp. 348-356, 2014.

2. K. Soleimani, A. D.Tehrani, and M. Adeli, Bioconjugated graphene oxide hydrogel as an effective adsorbent for cationic dyes removal, Ecotoxicology and Environmental Safety, Vol. 147, pp. 34-42, 2018.

3. S. Liu, H. Ge, C. Wang, Y. Zou, and J. Liu, Agricultural waste/graphene oxide 3D bio-adsorbent for highly efficient removal of methylene blue from water pollution, Science of the Total Environment, Vol. 628-629, pp. 959-968, 2018.

4. E. Kusrini, A.K. Sasongko, Nasruddin, and A. Usman Improvement of carbon dioxide using graphite waste $/ \mathrm{Fe}_{3} \mathrm{O}_{4}$ Composites, International Journal of Technology, Vol. 8, pp. 1436-1444, 2017.

5. E. Kusrini, A. Usman, Nasruddin, C. S. Utami, and K. A. Tito, Applicability of graphite waste composites and Ceria for Carbon Dioxide Adsorption, International Journal of Technology, Vol. 2, pp. 37-45, 2018

6. E. Kusrini, B. Wicaksono, Y. Yulizar, E.A. Prasetyanto, C .Gunawan, Textile Dye Removal from Aqueous Solution using Modified Graphite Waste/Lanthanum/Chitosan Composite, In: IOP Conf. Series: Materials Science and Engineering, Vol. 316, 012029, 2018.

7. E. Kusrini, C.S. Utami, Nasruddin, E.A. Prasetyanto, Aji A Bawono, Preparation and Characterization of Graphite Waste $/ \mathrm{CeO}_{2}$ Composites, In: IOP Conf. Series: Materials Science and Engineering, Vol. 316, pp. 012030, 2018.

8. R.A. Escalona-Villalpandoa, M.P. Gurrolaa , G. Trejoa, M. Guerra-Balcázarb, J. Ledesma-Garcíab, L.G. Arriaga, Electrodeposition of gold on oxidized and reduced graphite surfaces and its influence on glucose oxidation, Journal of Electroanalytical Chemistry, Vol. 816, pp. 92-98, 2018.

9. L. Peng, P. Qina, M. Lei, Q. Zeng, H. Songa, J. Yang, J. Shao, B. Liao, and J. Gu, Modifying $\mathrm{Fe}_{3} \mathrm{O}_{4}$ nanoparticles with humic acid for removal of Rhodamine B in water, Journal of Hazardous Materials, Vol. 209-210, pp. 193-198, 2012.

10. M. H. Do, N. H. Phan, and T. D. Nguyen. Activated Carbon/ $/ \mathrm{Fe}_{3} \mathrm{O}_{4}$ nanoparticle composite: Fabrication, Methyl Orange removal and regeneration by hydrogen peroxide. Chemosphere, pp. 1269-1276, 2011.

11. Martin-Gullon, J. M.-D., Types of Carbon Adsorbents and their Production. Activated Carbon Surfaces in Environmental Remediation, Interface Science and Technology Series, pp. 1-48, 2006. 
12. C. Cao, L. Xiao, C. Chen, X. Shi, Q. Cao, L. Gao, In situ preparation of magnetic $\mathrm{Fe}_{3} \mathrm{O}_{4}$ /chitosan nanoparticles via a novel reduction-precipitation method and their application in adsorption of reactive azo dye, Powder Technology, Vol. 260, pp. 90-97, 2014. 